\title{
INVESTIGATION OF THE BIOLOGICALLY ACTIVE SUBSTANCES CONTAINED IN FOREST FRUITS FOR THE PURPOSE OF USING THEM AS A RAW MATERIAL FOR THE PRODUCTION OF FUNCTIONAL BEVERAGES
}

\author{
Radostina Stefanova, Antoaneta Georgieva, Krasimir Krastev \\ Faculty of Technices and Technologies of Yambol, \\ Trakia University of Stara Zagora, Bulgaria \\ Graf Ignatiev 38, 8600, Yambol, Bulgaria \\ e-mail: antoaneta.georgieva@trakia-uni.bg, krasimir.krastev@trakia-uni.bg
}

\begin{abstract}
Were studied chemical composition, total content of anthocyanins pigments and aminoacid composition in forest fruits S. ebulus L., Vaccinium myrtillus L., Rubus caesius L., Ribes nigrum, Vaccinium vitis idaea $L$. and Grataegus monogyna for the purpose of using them as a raw material for the production of functional beverages. In the course of the work, it has been established that the berries are a valuable raw material for obtaining functional beverages. They are the source of many biologically active substances such as vitamins, polyphenol compounds, pigment and pectin substances, amino acids and macroelements.
\end{abstract}

Keywords: forest fruits, anthocyanins, biologically active substances, macroelements, vitamins, functional beverages.

\section{INTRODUCTION}

One of the main conditions for the creation of functional food products of a new type is the achievement of the maximum possible level of its nutritional and biological value and guaranteed safety.

Beverages are an optimal form of food that can be used to enrich the nutritional portion of every person with all irreplaceable nutrients and biologically active substances that have a beneficial effect on metabolism and immune resistance of the body [1].

When solving the problem of eating significant role has drinks based on natural plant materials, of which a significant place is determined of the juices and.

At the present time, given the low resistance of the human organism of the negative influence of the environment, one of the main tasks of the food industry is the production of food products with healing properties.

In order to increase the nutritional value of juice - containing products, in manufacturing technology can be introduced wild sylvan raw materials having prophylactic and functional performance.

The composition of some forest fruits is studied [2].

The therapeutic potential of the wild bushes are consists in their antioxidant, antiinflammatory and antiviral properties that depend on the polyphenol complexes. Particular attention is paid to the content of flavonoids and anthocyanins pigments.

Anthocyanins are water-soluble plant pigments determining the red, blue and violet color of the fruit. They are glycosides of flavones aglycones (anthocyanidins). Qualitative composition of anthocyanins is specific to the type of plant. 


\section{MATERIAL AND METHODS OF WORK}

Object of study are the fruits of S. ebulus L., Vaccinium myrtillus L., Vaccinium vitis idaea L., Rubus caesius L., Ribes nigrum and Grataegus monogyna. In wild plants are contain a number of chemicals that can affect the vital processes occurring in the human body.

The physicochemical parameters were determined by the following methods:

Dry substance - refractometric,\% BSS 17257-91.

Determination of moisture - Weight analysis / gravimetry / - BDS - SR ISO 6496.

Determination of protein - Kjeldahl - BDS - EN 25663 - SR ISO 5983.

Total sugars,\% BDS 7169-89.

Pectic substances,\% BSS 16591: 1987.

Organic acids - BDS - EN 60204-1: 2006.

Determination of tannins - titrimetric by exhaustion with hot water at reflux and titration of the exhaustive extraction with $0,1 \mathrm{n} \mathrm{KMnO} 4$ with indigo carmine indicator.

Assay of ascorbic acid, mg\% BDS 11812-91.

BDS - EN 14122: 2014 Vitamin B1 by High Performance Liquid Chromatography.

BDS - EN 14152: 2014 Vitamin B2 by High Performance Liquid Chromatography.

BDS - EN 14164: 2014 Vitamin B6 by High Performance Liquid Chromatography.

BDS - EN 12822: 2014 Vitamin E.

BDS - EN 12823-2: 2001 Vitamine A (beta-carotene).

Vitamin PP - nicotinic acid - colorimetric method [3].

Vitamin P - bioflavonoid (rutin, citrine, catechins, etc.) is a complex of compounds called bioflavonoids [4].

Determination of macro - and microelements ( $\mathrm{Ca}, \mathrm{Na}, \mathrm{K}, \mathrm{Mg}, \mathrm{Fe}, \mathrm{Mn}$ ) - atomic absorption spectrometry.

Determination of phosphor - colorimetric method - BDS 11374.

Determination of chlorides - BDS 17318: 1993.

Amino acid composition - ion exchange column chromatography/ Moore and Stein method BDS - AOAC, 20071 (amino acid).

The total content of the anthocyanins was determined on State Pharmacopoeia of Russia. General methods of analysis [4].

Swallowing anthocyanins pigments depends on the $\mathrm{pH}$ of the solution. In acidic environment coloring of most anthocyanins is bright red. By increasing the $\mathrm{pH}$ gradually turns dark blue. The difference in adsorption measured at a wavelength of $510 \mathrm{~nm}$ at $\mathrm{pH}=1$ and $\mathrm{pH}=5$ is proportional to the content of anthocyanins pigments.

\section{RESULTS AND DISCUSSION}

The purpose of this work is to investigate the chemical composition, the total content of anthocyanic pigments and the amino acid composition in the forest fruits $S$. ebulus $L$., Vaccinium myrtillus L., Rubus caesius L., Ribes nigrum, Vaccinium vitis idaea L.and Grataegus monogyna.

Compared to other species of S. nigra L. and S. racemosa L., S.ebulus L. contains larger amounts of nutrients and most vitamin C.

Isolated are the organic acids malic, tartaric, citric, succinic and valerianic.

Fructose accounts for a significant amount of sugars. The fruits also contain glucose and a little sucrose.

Unlike other fruits, S.ebulus L. contains more pectin, tannins, dyes, and mineral salts.

The fruits of S.ebulus L. contain anthocyanins, anthocyanidins and flavonoids. 


\section{IRTTL $\vee$}

Ipplied Resseirlohes in Technics, Technologies and Eductition

Journal of the Faculty of Technics and Technologies, Trakia University https://sites.google.com/a/trakia-uni.bg/artte/

The fruits of Grataegus monogyna (hawthorn) are rich in sugars, pectin, organic acids, mineral salts, vitamin $\mathrm{C}$ and $\mathrm{B} 1$, which makes them nutritionally and biologically valuable.

Between sugars, fructose dominates, followed by the sucrose. Isolated are the organic acids malic, succinic and tartaric. Isolated is krategova acid which is not contained in other fruits.

Contains 15 flavonoid glycosides (hyperoside, vitixine, quercetin, hyperine, vitixinrhamnoside, trimethylamine, oxyacantine, etc.), aminopurines, alkylamines and others.

Grataegus monogyna (hawthorn) has a good healing effect in functional heart disorders.

The fruit of Rubus caesius (blackberry) in a chemical composition is similar to that of the raspberry, but is richer of the macroelements potassium, calcium, magnesium, iron, and from trace element copper $170 \mu \mathrm{g} \%$.

Of the vitamin composition, the vitamin $C$ content is lower, but vitamin $P$ values are higher. Sugars contain mainly fructose and glucose and a negligible amount of sucrose. There is a large amount of tannins and dyes (anthocyanins, anthocyanidins, flavonoids, etc.).

On the high content of tanning substances is due the tingling flavor of the forest blackberries. Isolated are the organic acids malic, citric, tartaric, succinic and salicylic citric, tartaric, succinic and salicylic. Due to its high potassium content and low sodium levels, the fruit is suitable for dietary food in cardiovascular and renal diseases.

Of the vitamins, the amount of vitamin $\mathrm{C}$ is high, which is preserved during storage due to the high content of organic acids and dyes. In an acidic environment, vitamin $\mathrm{C}$ is more durable.

The fruit of the black bilberry (Vaccinium myrtillus L.) contains many sugars (fructose and glucose predominate and sucrose is insignificant), pectin substances, organic acids (malic, citric, tartaric, ursic, lactic, antaric, oxalic, quinine, etc.).

The fruit has a diverse mineral composition. Contains macro- and many micro elements. Of all fruits, the fruit of the bilberry has the highest manganese content.

Contains glycosides (myrtilin, neomyrtilin, vaccinin, ericolin, arbutin, isocvercetine, avicularin) and anthocyanins. Myrtlein and neomycin, which can lower blood sugar in diabetes mellitus, are involved in composition dyestuffs substances.

By many indicators, the fruit of the red blueberries (Vaccinium vitis idaea L.) is approaching that of black blueberries. It has a richer composition of organic acids. It contains benzoic, salicylic, senile, uksusna acid.

Isolated glycosides are vaccinin, arbutin, methylarbutin, quercetin, isoquercetin and hyperoside. Of the trace elements are contain a large amount of manganese.

The fruit of black currant (Ribes nigrum) is a natural vitamin concentrate, especially with its high levels of vitamin $\mathrm{C}$, vitamin $\mathrm{P}$ and carotene.

In this respect, is superior of many fruits, including of the lemons. Sugars are mainly fructose and glucose.

The fruit of black currant is rich in organic acids - citric (1.3-2\%), malic (0.25-1.87\%), oxalic $(0.06 \%)$, succinic $(60 \mathrm{mg} \%)$, fumaric and caffeic $40 \mathrm{mg} \%)$, chlorogenic and salicylic (20 $\mathrm{mg} \%)$, quinine (10 $\mathrm{mg} \%)$, tartaric and nicotinic acids.

Contains many pectin and dye substances. The fruit is rich in mineral substances, macroand microelements, glycosides and amino acids.

Dyestuffs together with calcium salts and the organic acids have a vitamin C stabilizing effect and protect against viral infections together with their flavonoids and flavonoidinite.

Three groups of substances relate to vitamin P: flavones, anthocyanins and L-catechins. In nature, these groups are mutually converted, flavonols through leuco-anthocyanidins can be converted or in anthocyanidins or in catechins. The conversion process is carried out continuously, so in the plant world, these groups are accompanied with one another. 
Anthocyanins belong to the P-active substances - substances in red contained in the studied wild plants. The amount of useful substances, vitamins and minerals is higher as compared to other berries. Therefore are products for healthy and rational nutrition. They help to boost immunity, heal and strengthens the body and are useful for various diseases.

The total concentration of the pigments is determined relatively one of them, such as cyanidin-3-glucoside - Figure1.

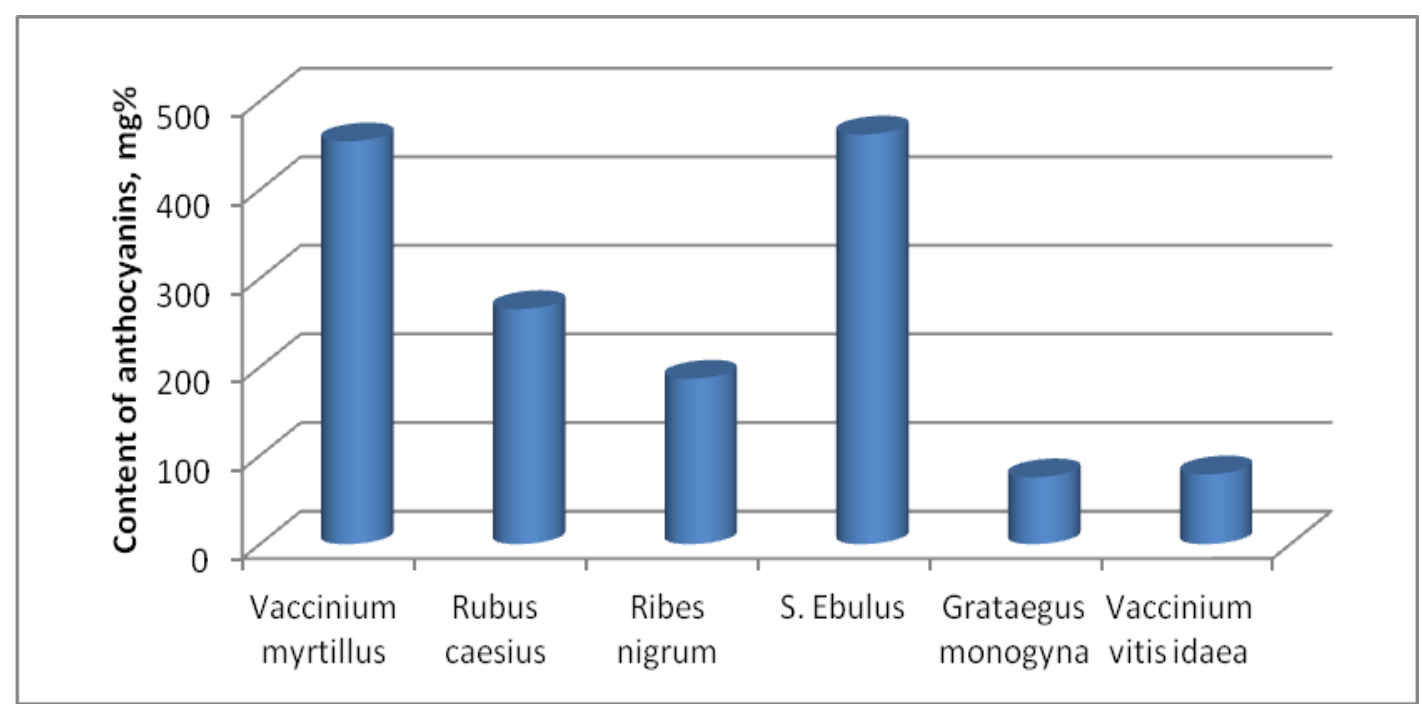

Figure 1.

Content of anthocyanins in the studied forest fruits

The data in Figure 1 shows that the highest is content of anthocyanins in S. ebulus L. and Vaccinium myrtillus L., следвано от Rubus caesius L., Ribes nigrum S., Vaccinium vitis idaea L. and Grataegus monogyna. The red fruits contain from 3 to 10 times less anthocyanins pigments than dark colored fruits.

For the determination of biologically active substances in the fruits of wild plants S. ebulus L., Vaccinium myrtillus L., Vaccinium vitis idaea L., Rubus caesius L., Ribes nigrum and Grataegus monogyna were studied the physicochemical their parameters. The results are given in Table 1, Figure 2, Figure 3, Figure 4 and Figure 5.

Table 1. Chemical composition of the fruits of the test plants, $\%$

\begin{tabular}{|l|c|c|c|c|c|c|}
\hline $\begin{array}{l}\text { Quantitative } \\
\text { indices, \% }\end{array}$ & $\begin{array}{c}\text { Vaccinium } \\
\text { myrtillus }\end{array}$ & $\begin{array}{c}\text { Ribes } \\
\text { nigrum }\end{array}$ & $\begin{array}{c}\text { Rubus } \\
\text { caesius }\end{array}$ & $\begin{array}{c}\text { S. } \\
\text { ebulus }\end{array}$ & $\begin{array}{c}\text { Vaccinium } \\
\text { vitis idaea }\end{array}$ & $\begin{array}{c}\text { Grataegus } \\
\text { monogyna }\end{array}$ \\
\hline Moisture & 84,6 & 86 & 86,9 & 81,5 & 86,5 & 75,5 \\
\hline Proteine & 0,96 & 1,9 & 1,15 & 1,5 & 1,25 & 1,35 \\
\hline All sugar & 9,4 & 12,3 & 6,5 & 10,1 & 10,6 & 8,5 \\
\hline Organic acid & 3,6 & 4,8 & 2,3 & 1,9 & 2,7 & 0,82 \\
\hline $\begin{array}{l}\text { Pectinous } \\
\text { substance }\end{array}$ & 1,9 & 2,8 & 1,8 & 0,9 & 1,2 & 0,75 \\
\hline $\begin{array}{l}\text { Tanning } \\
\text { extracts }\end{array}$ & 0,45 & 0,8 & 0,5 & 1,6 & 1,5 & 0,94 \\
\hline
\end{tabular}




\section{IRITIE

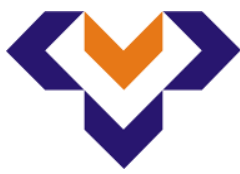

Ipplied Resseirlores in Technics, Technologies and Educration

Journal of the Faculty of Technics and Technologies, Trakia University https:///ites.google.com/a/trakia-uni.bg/artte/

As can be seen from the data presented, the bulk of the dry matter in the fruit studied is from $13.1 \%$ in Rubus caesius to 24.5 in Grataegus monogyna. Most of them are digestible carbohydrates and organic acids.

The digestible carbohydrates in the forest fruits are mono- and disaccharides - glucose, fructose and partially sucrose.

The organic acid content of the studied berries is $0.82 \%$ for Grataegus monogyna to $4.8 \%$ for Ribes nigrum. They play an important role in preserving fruit and juices, determining their acidic taste, stimulating intestinal peristalsis, excite pancreas secretion, and have a bactericidal action

Sugars contained in the fruits examined mask their sour taste.

The bulk of pectin substances in the test fruit is from $0.75 \%$ in the case of Grataegus monogyna to $2.8 \%$ in Ribes nigrum.

Pectin normalizes microflora in the intestine and removes cholesterol from the body. It forms insoluble complexes with toxic and radioactive metals, removing them from the body.

The nutritional value of berries is also determined by the presence of vitamins and macroelements.

Mineral salts are an essential ingredient of forest fruits. They participate in important vital functions of the body: in the construction of the bone skeleton; in regulating osmotic, oncotic and hydrostatic pressures for the proper flow of physico-chemical processes governing the movement of water between capillary blood plasma and intracellular fluid; the formation of blood, in blood clotting, etc.

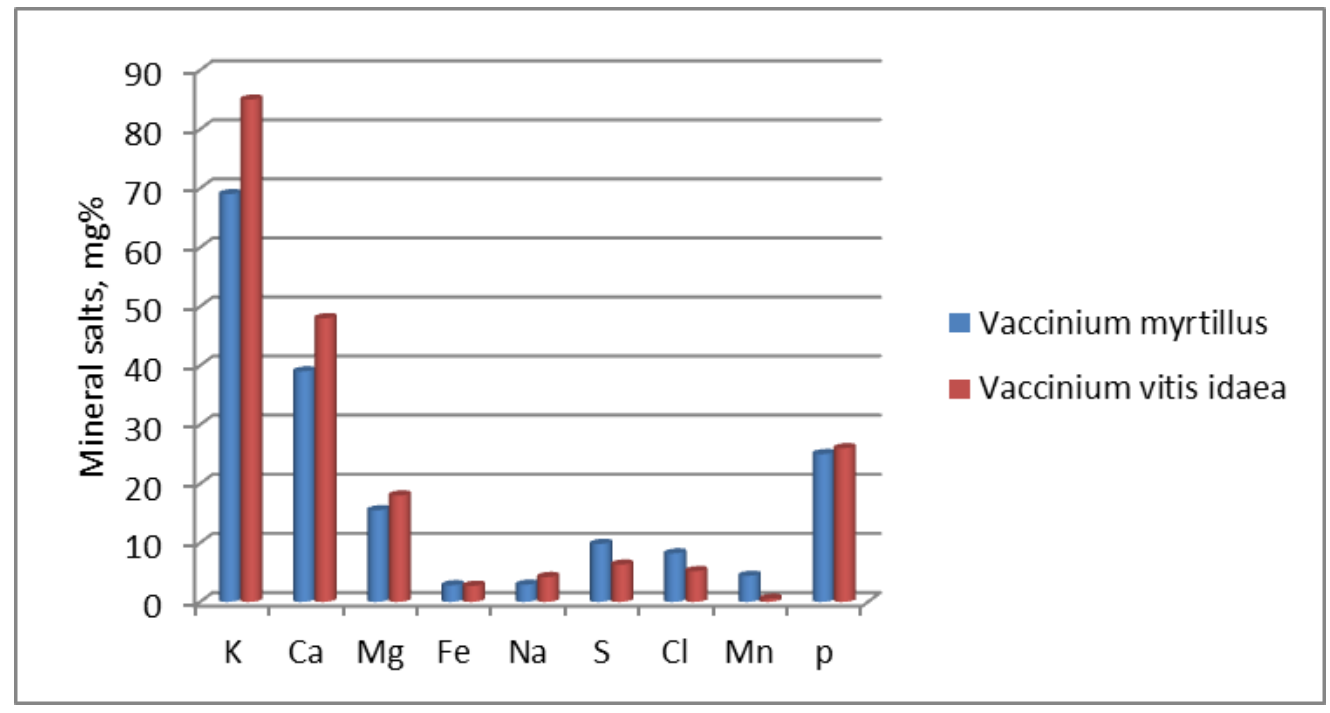

Figure 2.

Mineral salts in the fruits of Vaccinium myrtillus and Vaccinium vitis idaea, $\mathrm{mg} \%$ 


\section{IRTIIE}

Ipplied Researreches in Technics, Technologies and Eductation Journal of the Faculty of Technics and Technologies, Trakia University https://sites.google.com/a/trakia-uni.bg/artte/

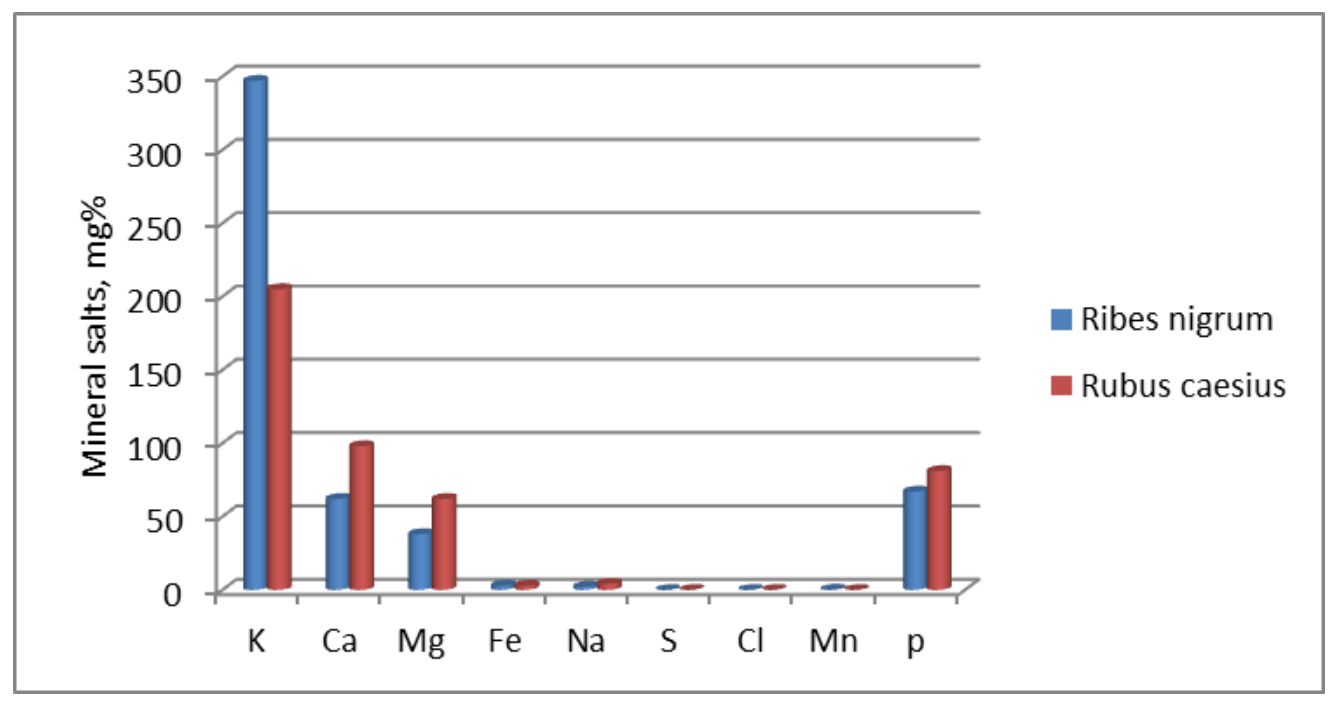

Figure 3. Mineral salts in the fruits of Ribes nigrum and Rubus caesius, mg\%

From macroelements the highest content of potassium, calcium, magnesium, phosphorus and iron.

Vaccinium myrtillus $L$. has various vitamin and mineral composition, but holds the record in content of manganese among the fruit.

The primary importance of forest fruits is due to their rich vitamin content. These are active substances that act in small quantities as regulators of metabolism. Vitamin C plays an extremely important role in the process of life processes and oxidation in the body. This vitamin is a natural antioxidant.

Ascorbic acid participates in the construction of the enzyme systems and the nucleic acids, in amino acid degradation, in glycolysis, glycogen synthesis and glycogen deposition, in the formation of blood and in blood clotting. It acts anti-inflammatory and is very important for growth and normal mental development.

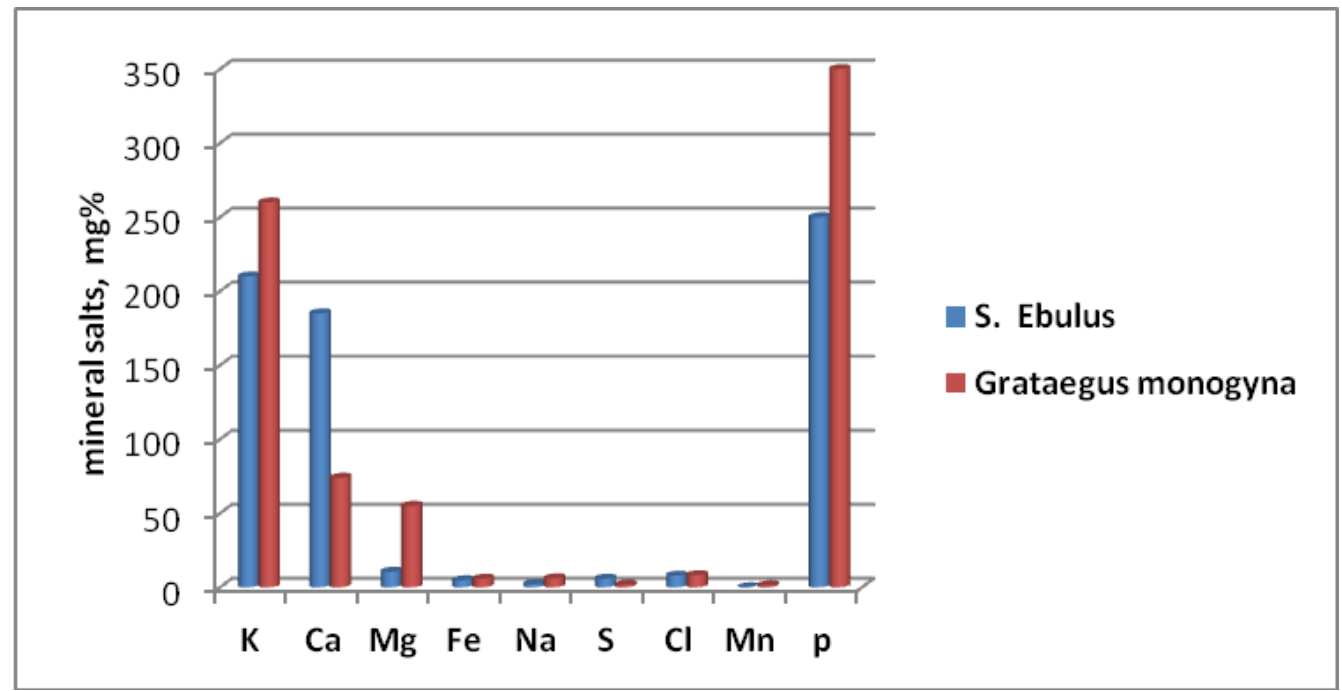

Figure 4. Mineral salts in the fruits of S. Ebulus and Grataegus monogyna, $\mathrm{mg} \%$

IRTIIE Vol. 5, No. 4, 2017 ISSN 1314-8788 (print), ISSN 1314-8796 (online), doi: 10.15547/artte.2017.04.011 


\section{IRT'TE Ipplied Ressearches in Technics, Technologies and Educration Journal of the Faculty of Technics and Technologies, Trakia University https://sites.google.com/a/trakia-uni.bg/artte/}

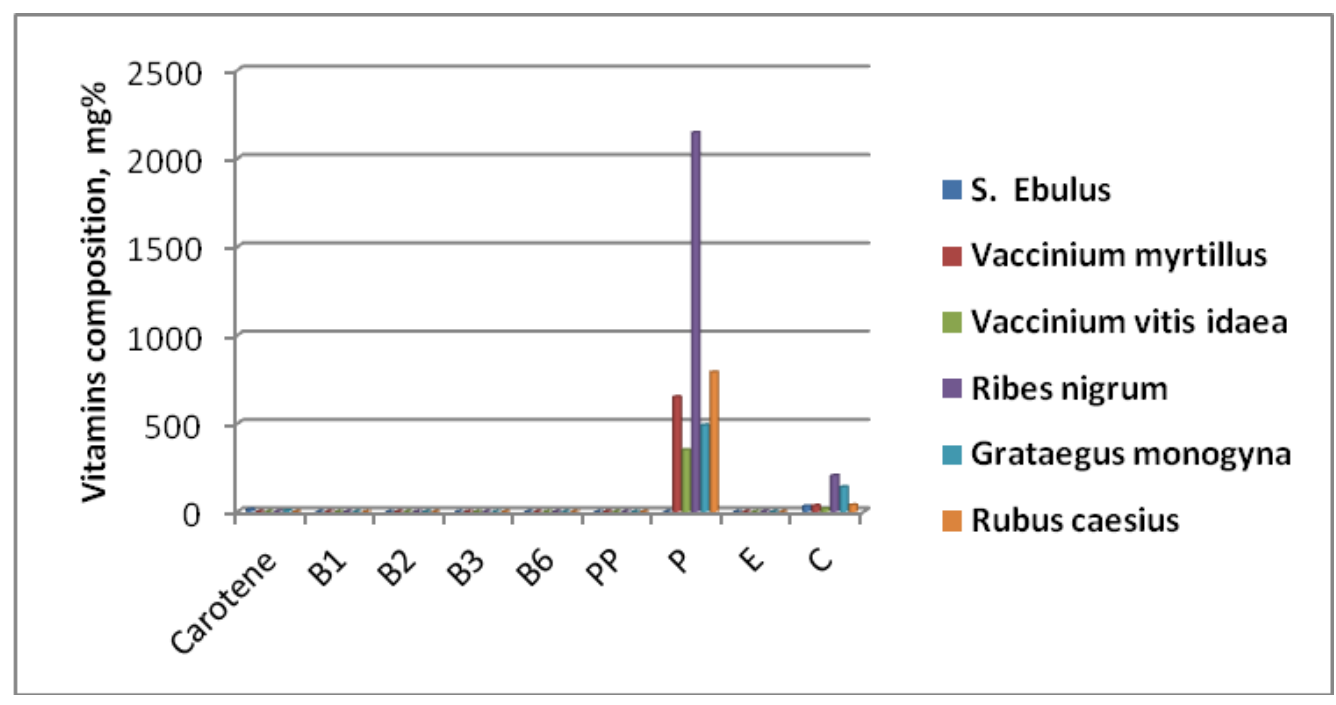

Figure 5. Vitamins composition of the fruits of the test plants, $\mathrm{mg} \%$

The fruit of Ribes nigrum is a vitamin concentrate with high levels of vitamin P and vitamin C. The fruit of Rubus caesius $L$. and of Vaccinium myrtillus contains a significant amount of vitamin $\mathrm{P}$.

Amino acids are not only a structural element of proteins and other endogenous compounds, but they are of great functional significance.

The qualitative composition and the content of the free essential amino acids in the studied berries were studied.

These amino acids are not synthesized in the body and enter the body through food.

The results of the analysis show that in forest fruits are contained 7 essential amino acids Figure 6 and figure 7.

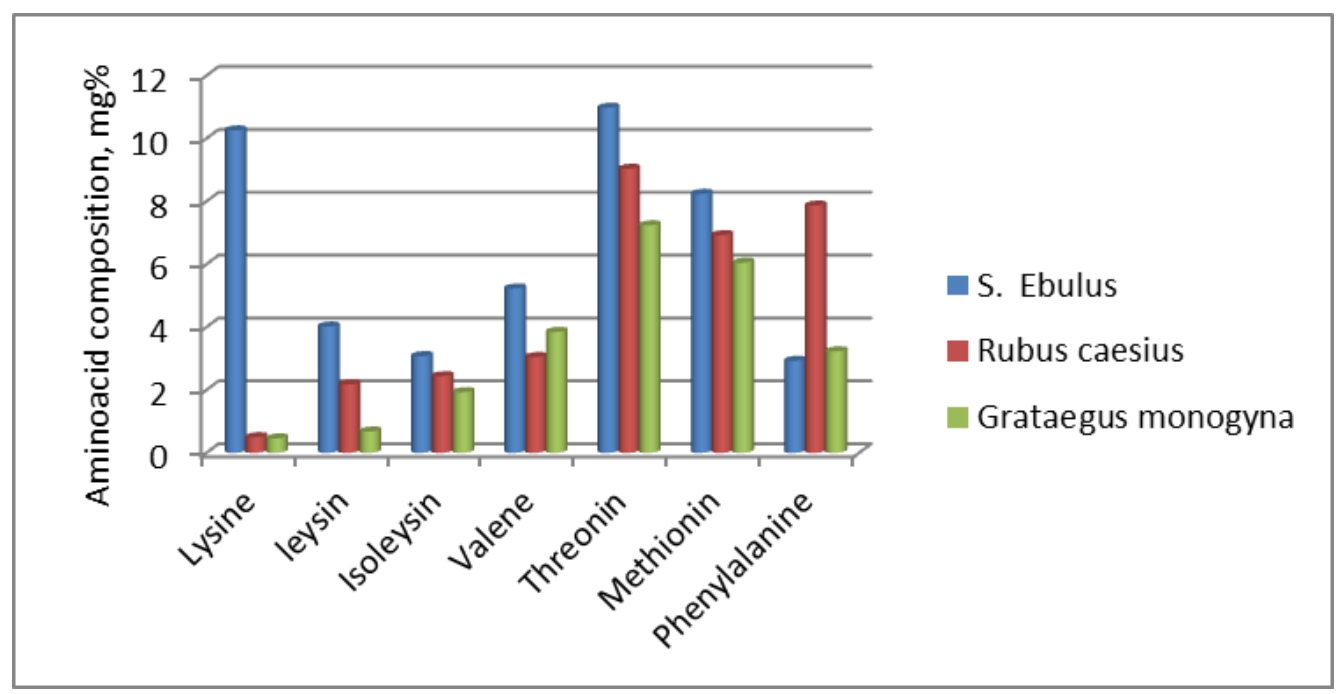

Figure 6.

Aminoacid composition of the fruits of $\mathrm{S}$. Ebulus, Rubus caesius and Grataegus monogyna, $\mathrm{mg} \%$

IRTITE Vol. 5, No. 4, 2017 ISSN 1314-8788 (print), ISSN 1314-8796 (online), doi: 10.15547/artte.2017.04.011 


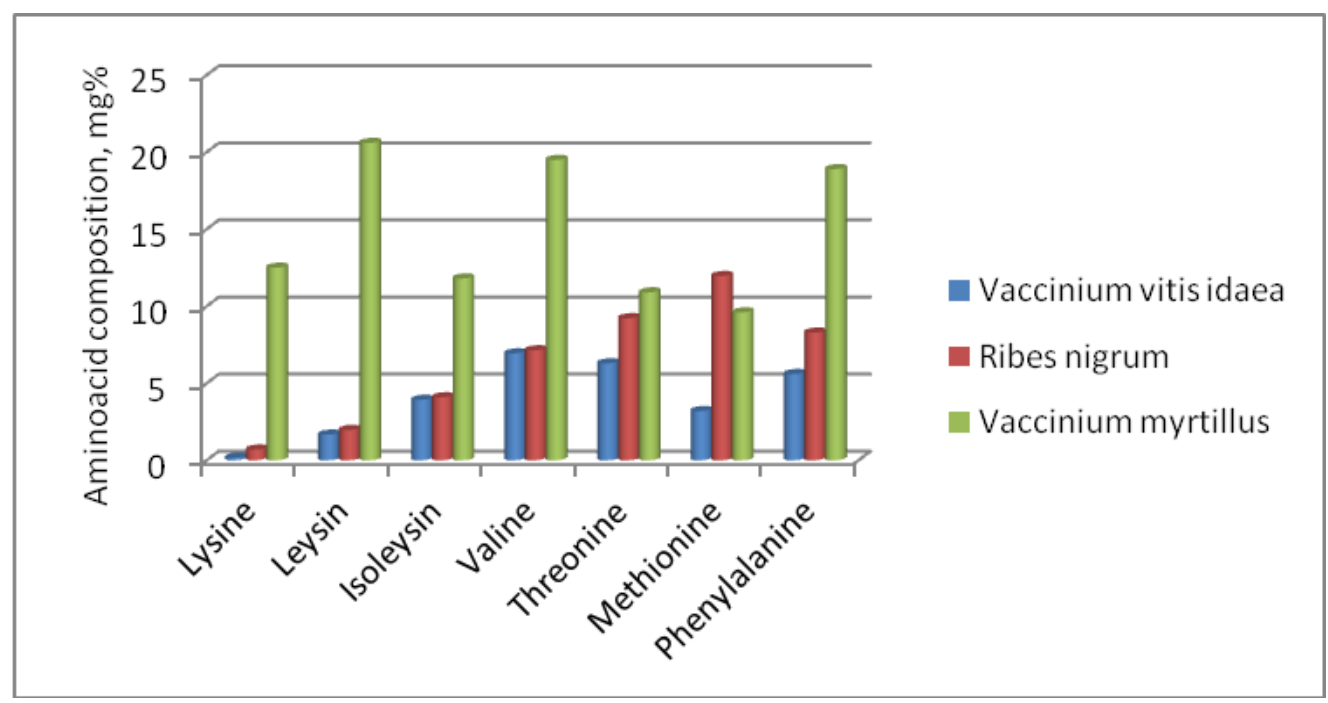

Figure 7.

Aminoacid composition of the fruits of Viburnum lantana L., Ribes nigrum and Vaccinium vitis idaea $\mathrm{mg} \%$

\section{CONCLUSION}

The analysis of the results shows that the studied forest fruits are rich in biologically active substances and can be used as a raw material for the production of functional beverages.

\section{LITERATURE}

[1] Akulinina, B. Enriched beverages - a new niche in the juice market / V. Akulinina // Containers and opakovka.-2007.- № 4. - P.16.

[2] Michev B. and Authors "Forest Food and Medicinal Products" Zemizdat, Sofia, 1983.

[3] Genadiev A. \& Co., Analysis of Food Products, Technika, Sofia, 1968.

[4] State Pharmacopoeia of Russia. General methods of analysis - II ed., Medicine. 1987. 